\title{
Performance of Socially Responsible Investment Funds in China: A Comparison with Traditional Funds
}

\author{
Fateh Saci ${ }^{1, *}$, Sajjad M. Jasimuddin ${ }^{2}\left(\right.$ and Morshadul Hasan ${ }^{3}{ }^{(1)}$ \\ 1 Hospitality Management, Institut Paul Bocuse, 69131 Ecully, France \\ 2 Strategy, Entrepreneurship, \& Sustainability Department, Kedge Business School, 13009 Marseille, France; \\ sajjad.jasimuddin@kedgebs.com \\ 3 Murdoch Business School, Murdoch University, Perth 6150, Australia; arif.morshad@gmail.com \\ * Correspondence: fateh.saci@institutpaulbocuse.com
}

check for updates

Citation: Saci, F.; Jasimuddin, S.M.; Hasan, M. Performance of Socially Responsible Investment Funds in China: A Comparison with Traditional Funds. Sustainability 2022, 14, 1476. https://doi.org/10.3390/ su14031476

Academic Editor: Andrea Pérez

Received: 8 November 2021

Accepted: 19 January 2022

Published: 27 January 2022

Publisher's Note: MDPI stays neutral with regard to jurisdictional claims in published maps and institutional affiliations.

Copyright: (C) 2022 by the authors. Licensee MDPI, Basel, Switzerland. This article is an open access article distributed under the terms and conditions of the Creative Commons Attribution (CC BY) license (https:// creativecommons.org/licenses/by/ $4.0 /)$.

\begin{abstract}
This paper empirically examines and compares social responsibility investment funds to traditional funds, and explores the performance of the existing social responsibility investment funds in China. Based on 64 social responsibility investment funds (SRI Funds) and 64 traditional funds, this paper extracts the data of the sample fund from the fourth quarter of 2016 to the fourth quarter of 2019 as sample data to conduct a comparative analysis of the difference between the SRI fund and the traditional fund in terms of return and risk, and to then empirically study the performance of the funds. The results show that the difference between the return of China's socially responsible investment funds and the traditional funds is insignificant, and the risk of socially responsible investment funds is significantly lower than that of traditional funds. The regression analysis is also carried out on a model of social responsibility as a factor affecting the performance of the funds. Subsequently, the results show that social responsibility has a significant positive impact on the fund's return in the Chinese market.
\end{abstract}

Keywords: socially responsible investment fund (SRI Fund); traditional funds; fund return; fund risk

\section{Introduction}

Sustainable development involves the use of environmentally responsible and efficient operational strategies, balancing corporate citizenship and environmental responsibilities to reward the communities in which the enterprise is located, and to protect the environmental resources that form the key success factors of the enterprise's long-term business. At the same time, corporate social responsibility will allow it to gain a good reputation in society, therefore attracting more investors and consumers, and increasing the potential upside for capital and profits [1]. Investment in environmental protection and employee welfare can ultimately reduce costs, increase employee motivation, and improve labor productivity. For investors, choosing socially responsible investment is also essentially one way to participate in sustainable development. By definition, socially responsible investments (SRI), also known by researchers and practitioners as ethical or sustainable investments [2,3] are an investment process that integrates ethical values, environmental protection, improved social conditions, and good governance into traditional investment decision-making [4-6]. According to Witt and Redding [7], to consider an investment as an SRI, the criteria used are R\&D expenditure, profitability, growth potential, payout ratio, and labor productivity growth rate. For the state, encouraging enterprises with good social responsibility performance and promoting the development of Chinese social responsibility investment will help to establish a healthy and green economic environment and a good foundation for long-term development [8].

Recently, scholars have emphasized the important role of social responsibility in investment choices in order to enhance concern towards social responsibility of all parties 
involved in the financial industry [9]. In this paper, we refer to the theory of sustainable development and stakeholder theory. According to Derwall et al. [1], the Socially Responsible Investment Fund conforms to the theory of sustainable development. A lot of discussion between scholars and policymakers has taken place about an urgent global transition toward sustainable development, to create new opportunities for changing environmental, social, and institutional systems. For scholars [10,11], the transition toward sustainable development allows for a rapid restructuring of institutions toward more effective governance and with a stronger emphasis on planetary concerns in investments, which shows how much the role of finance has changed. In the past, the goal of all companies was maximizing shareholders' wealth, whereas currently a lot of companies care about environmental issues, such as the green economy and the climate change [12,13]. The integration of CSR and ESG criteria into SRI strategies justifies investment decisions including decisions of institutional investors, which play an essential role in the transition toward a more responsible and sustainable finance (micro-level), as well as toward a more sustainable development (macro-level) [12,14]. With the rapid development of the Chinese economy, people's living standards are gradually improved. At the same time, environmental pollution and other social problems are evolving. In recent years, corporate frauds such as money laundering, false statements insider trading, price fixing, child labor, and other unethical issues are becoming common. In China, social responsibility rules but the moral standards of companies are unclear. Through screening strategy, the socially responsible investment fund is chosen by those enterprises which are keen to contribute towards environmental and social areas.

Furthermore, stakeholder theory is a theory of business ethics that involves managing the ethics and values of the organization $[15,16]$. Stakeholder theory can explain why companies must assume social responsibility. A company can not only pursue the economic returns of shareholders, but also consider factors such as employees, society, and the environment. Stakeholder theory is also used to construct the framework of the corporate social responsibility evaluation system. It clarifies the objects of corporate social responsibility, and thus develops various quantifiable indicators in the modern corporate social responsibility evaluation system. Qi et al. [17] empirically tested the influence of mutual fund networks in China on corporate social responsibility behaviors, showing that mutual fund investors have a positive impact on a company's corporate social responsibility performance. Moreover, new evidence is found on how mutual fund investors affect corporate social responsibility performance, which is meaningful to examine in corporate green governance.

The article aims to empirically study the performance of mutual funds in China in terms of social responsibility. With this aim in mind, the research is conducted on the basis of the verification of four hypotheses (marked with numbers-1, 2a, 2b, and 3). The paper focuses on the comparative analysis of the difference between the SRI fund and the traditional fund in terms of return and risk, and empirically studies the performance of the fund. The remainder of the paper is structured as follows. Section 2 reviews the relevant literature and the theoretical basis. Section 3 contains the research hypothesis. The research design is elaborated on in Section 4. Section 5 presents and discusses our empirical results. Some concluding remarks are made in Section 6.

\section{Literature Review and Theoretical Basis}

\subsection{Socially Responsible Investment}

Social responsibility is manifested in many aspects (i.e., economic, social, environment) to safeguard the interests of multiple stakeholders to improve their credibility in information disclosure to investors [18]. When investing in the fund, the economic, social, and environmental benefits shall be taken into consideration. The social impact of investment has caused investors to develop the idea of socially responsible investment. The Forum for Sustainable and Responsible Investment noted: Socially responsible investment is a kind of 
investment which uses negative and positive investment selection strategy and considers the social and environmental impact of investment.

Hamilton et al. [19] classified these investment preferences as socially responsible investments. These investments serve as "agents" of individual investors motivated by socially ethical goals, as well as "principals" of companies chosen on the basis of respect for the natural, social, and economic environment. Over the past three decades, as interest in corporate responsibility and social performance has grown, a broad academic debate on ethical finance has unfolded. The research direction mainly focuses on the performance of socially responsible investors [20].

Some scholars [21,22] argue that SRI underperforms traditional funds. Hickman [23] says that investors choose a portfolio based on two factors - earnings and risk - and that social responsibility is not about investment decisions.

Compared with other countries, the research of social responsibility investment in China is still in the initial stage. China is now the second largest economy in the world and globally influential companies are in operation. China is rapidly becoming a world economic power [24]. Hence, China cannot ignore corporate social responsibility [25]. The Ethical Investment and Its Trend published by Li [26] introduced the concept of social responsibility investment in the West for the first time. Dai and Liu [27] analyzed the reasons of social responsibility investment rising from the angle of social development, and made a proposal for the potential development of social responsibility investment funds in China. Qiao and Long [28] empirically studied the performance level of socially responsible investment from the aspect of asset portfolio, arguing that listed companies in China's capital market have a positive response to the disclosure of socially responsible investment information. Lai [29] contends that social responsibility stock funds in China are the same as the general equity funds, which shows that social responsibility investment funds in China have development potential and investment value. Therefore, this paper tries to use the empirical analysis research method (our analysis method is already used by other researchers for the same research subject) to compare Chinese current social responsibility investment funds and traditional funds, to explore whether social responsibility is conducive to funding performance.

\subsection{The Relationship between ESG and Corporate Performance}

Several researchers [30-32] have studied the relationship between China's ESG and corporate performance. For example, Broadstock et al. [30] argue that there is a positive relationship between ESG performance and both stock market performance and long-term performance. For the authors, high ESG performance can be seen by investors, decision makers, company management, and industry regulators as a signal of future stock performance. Parallel to this, Deng and Cheng [31] contend that there is a positive relationship between a company's ESG indices and its stock market performance, which at the same time achieves a "win-win" situation between social value and business development. They also reveal that the influence of ESG indices on non-state-owned enterprises is greater than that on state-owned enterprises.

Other scholars found that companies seeking ESG development will benefit in terms of reputation, attractiveness to investors, innovation, and employee satisfaction [33], which can have a positive impact on stock market performance [34]. According to the study by Huber et al. [35], investors are increasingly convinced that by combining ESG with investment processes, they can fully realize the long-term benefits. Similarly, Henriksson [36] found that companies with higher ESG scores are more likely to have lower investment costs and higher credit ratings. The empirical results of Ghoul et al. [37] reveal that companies performing exceptionally well in one of the three areas, including environment, corporate governance, and corporate social responsibility, may reduce financing costs of the company. 


\subsection{Portfolio Theory and Capital Asset Pricing Model}

The modern Portfolio Theory proposed by Markowitz [38] is a theory on how riskaverse investors can construct portfolios to optimize or maximize expected return based on a given level of market risk. A financial portfolio is a collection of financial assets held by an institution or individual, including securities held as investments, deposits, provisions, or collateral. Portfolio theory shows how rational investors optimize portfolios. Rational investors are exposed to investment choices by essentially considering only two factorsearnings and risk. They maximize expected returns at a given risk level, or minimize expected risks at a given yield level.

Since then, Sharpe (1964) [39] proposed the capital asset pricing model CAPM based on portfolio theory, highlighting the mathematical relationship between return and risk. The model form is as follows:

$$
E\left(r_{i}\right)=r_{f}+\beta_{i}\left[E\left(r_{m}\right)-r_{f}\right]+\text { error }
$$

In the formula, $E\left(r_{i}\right)$ is the expected rate of return of the asset, $r_{f}$ is the risk-free rate, $\beta_{i}$ measures the systemic risk, and $E\left(r_{m}\right)$ is the expected rate of return of the market. The capital asset pricing model reveals that investors can obtain higher returns only by taking on higher risks.

\subsection{Screening Methods: The Strategy of Socially Responsible Investment}

The investment strategy of socially responsible investment includes the screening of investment portfolios. There are two types of screening methods: Negative Screening and Positive Screening. What has happened in the financial markets over the past 10 years has led people to re-examine investment choices from the perspective of ethical finance. The first is the collapse of the Internet (The first is the Internet bubble in the last 1990s), then the explosion of the real estate bubble, and finally the European sovereign debt crisis, which Kempf and Osthoff [40] and Freeman and Auster [41] say are prompting people to revisit the relationship between ethics and business. Argandona [42] pointed out that although the successive crises of the past few years have different characteristics, they all have bad ethical behaviors and cannot pass the screening criteria for socially responsible investment. Proponents of socially responsible investment believe that socially responsible investment can avoid the risks that are not considered in the traditional investment choice principle, thereby reducing the risk of the portfolio. Michelson et al. [43] and Capelle-Blancard and Monjon (2014) [44] argue that an active screening strategy for social responsibility will bring higher returns to the portfolio.

Negative screening refers to avoiding investment in companies that are harmful to society, such as those engaged in tobacco, alcohol, gambling, weapons, and other related industries, as well as enterprises involved in such immoral acts (unethical behaviors) such as discrimination, infringement, environmental pollution, and animal experiment, etc. Investors believe that investing in these companies is equivalent to indirectly supporting bad behaviors that undermine social stability, and violates their investment objectives (financial, environmental, social, and societal objectives). Active screening refers to active selection of companies that perform well in social responsibility; these companies have more social responsibility, and therefore have a better reputation and social status, can bring investors more benefits, and make a positive impact on society. Carswell [45] believes that negative screening strategies would exclude some investments from the portfolio of socially responsible portfolios. Lewies and Mackenzie [46] noted that investors who chose socially responsible investments were willing to accept lower-yielding securities. In the actual operation of the socially responsible investment fund, the fund manager generally combines the financial situation of the enterprise with the investment of not less than $80 \%$ of the investment portfolio in the enterprise under the active screening strategy [47]. 


\subsection{Fund Performance and Risk Assessment Indicators}

\subsubsection{Rate of Return}

The rate of return reflects the level of return on investment and is generally expressed as an annualized percentage. Calculate the fund's actual rate of return $R$ using the fund's net return $N A V$. The expression is as follows:

$$
R_{i, t}=\frac{N A V_{i, t}-N A V_{i,(t-1)}+D_{t}}{N A V_{i,(t-1)}}
$$

In the formula, $R_{i, t}$ represents the yield or return of $\mathrm{i}$ fund in the $t$ period, $N A V_{i, t}$ represents the unit net value of the $i$ fund at the end of the $t$ period, and $D_{t}$ represents the unit cash dividend of the fund in the $t$ period.

\subsubsection{Standard Deviation $\sigma$}

The standard deviation reflects the volatility of the rate of return during the period under review, and describes the deviation of the weekly or monthly rate of return of the fund from the average weekly or monthly rate of return. The greater the standard deviation, the greater the volatility. This leads to the greater the relative risk to the fund.

\subsection{3. $\beta$ Coefficient}

The $\beta$ factor is a tool used to measure the systemic risk of assets (to measure the risk of the entire investments). It measures the overall volatility of fund returns relative to market benchmarks, a relative measure. The higher the $\beta$, the more volatile the fund is relative to the performance benchmark. The calculation formula is as follows:

$$
\beta=\frac{\operatorname{COV}\left(r_{a}, r_{m}\right)}{\sigma_{m}^{2}}
$$

In the formula, $r_{a}$ is the return of fund $a, r_{m}$ is the benchmark return of the market where the fund is located, $\operatorname{COV}\left(r_{a}, r_{m}\right)$ is the covariance of the two returns, and $\sigma_{m}^{2}$ is the variance of the market benchmark return.

Generally, the absolute value calculated by regression analysis method is the value of $\beta$ coefficient. $\beta=1$, which means that the fund returns change with market returns, and if the market goes up or down by $10 \%$, the fund goes up or down by $10 \%$ (this is just an example to explain the meaning of Beta $=1$ ), and the fund risk equals the market risk. $\beta>1$, which means funds are more volatile than markets, such as $\beta=1.1$, where the market is up or down $10 \%$ and funds are up or down $11 \%$. $\beta<1$, which means funds are less volatile than markets, such as $\beta=0.9$, where the market is up or down $10 \%$ and funds are up or down $9 \%$.

\subsubsection{Jensen's Alpha}

The Jensen Alpha Index describes the excess return of a portfolio * that exceeds the theoretical expected return, which is the difference between the actual return and the theoretical expected return [48]. Its calculation formula is as follows:

* Excess returns are the return earned by a portfolio of stocks and the risk-free rate, which is usually estimated using the most recent short-term government treasury bill. For example, if a stock earns $15 \%$ in a year when the U.S. treasury bill earned 3\%, the excess returns on the stock were $15-3 \%=12 \%$.

$$
\alpha_{J}=R_{i}-\left[R_{f}+\beta_{i m} \cdot\left(R_{m}-R_{f}\right)\right]
$$

In the formula, $R_{i}$ is the actual return of the portfolio, $R_{f}$ is the risk-free return, $\beta_{i m}$ represents the beta coefficient of the portfolio, and $R_{m}$ is the market benchmark return.

If $\alpha>0$ calculated by the regression analysis method, it means that the actual return of the asset is higher than its expected theoretical. Jensen [48] measured a fund manager's 
performance against the returns that could have been expected from a market-related investment, while adjusting for the fund's correlation to that market.

\section{Research Hypotheses}

\subsection{The Return of Socially Responsible Investment Funds}

Orlitzky et al. [49] pointed out that socially responsible investment-chosen firms have sustainable competitive advantages, smaller information asymmetries, and good relationships with financial markets. In terms of competitiveness, Renneboog et al. [50] highlights the following key advantages: It is necessary to improve productivity and retain talent in a safer and more active work environment. Renneboog et al. $[6,50]$ expressed the view that socially responsible investment can reduce economic and social risks resulting from environmental damage. Bringer and Benforado [51] highlighted that energy conservation policies can improve operational efficiency; Fassin [52] said that strategies to reduce environmental impacts have improved the ability of firms to innovate. Nielinger [53] believes that corporate image improvement increases customer loyalty and bring greater market opportunities. In addition, Hamilton et al. [19] noted that a more stable and transparent relationship with capital markets can reduce costs. Hence, we formulate the following hypothesis.

Hypothesis 1. The return of socially responsible investment funds is higher than that of traditional funds.

This hypothesis comes from a study in which Margolis and Walsh [54] are positively related to the synergy between socially responsible investment returns and corporate social responsibility performance and economic financial performance.

\subsection{The Volatile and the Systemic Risk of Socially Responsible Investment Funds}

There are not enough social responsibility investment funds in China. Companies with sustainable competitive advantages seem to make investments more stable than in the traditional funds. In fact, the companies investing in SRI funds are more legitimate because of their moral and social behavior, which contributes to more stability and viability than other companies. Higher stability in terms of social responsibility, compared to traditional funds, can reflect the lower risk of socially responsible investing. This has almost become a feature of socially responsible companies.

Moreover, the screening strategy of socially responsible investment funds can help to achieve a better risk-return relationship compared to traditional funds. Cortez et al. [55] noted that the reduction in information asymmetry could compensate for the potential loss of diversification in socially responsible portfolios through higher quality and more information disclosed by socially responsible companies. In this sense, socially responsible investment funds can protect investments from being affected by market benchmark fluctuations. Accordingly, we developed the following hypotheses.

Hypothesis 2a. Socially responsible investment funds are less volatile than traditional funds.

Hypothesis $\mathbf{2} \mathbf{b}$. The systemic risk of socially responsible investment funds is lower than that of traditional funds.

\subsection{Corporate Social Responsibility as a Factor of Investment Choice}

This assumption is related to the two preceding assumptions. In this paper, corporate social responsibility is considered as a factor of investment choice. It seems to have a positive impact on fund returns. In order to validate this assumption (verify this hypothesis), it is necessary to control some variables that affect the fund's returns, such as: system risk, fund scale, company size, net assets, management capacity, and investment field, etc. This suggests the following hypothesis. 
Hypothesis 3. Corporate social responsibility has a positive impact on fund returns.

\section{Research Design}

\subsection{Sample Selection and Data Sources}

This paper takes China's socially responsible investment fund as the main unit of analysis. This paper will select Chinese social responsibility investment funds, compare these with the traditional funds, and perform an empirical analysis of the income, return, and risk levels of the two funds so as to observe the performance and potential risk of existing social responsibility funds in China. Although the Chinese social responsibility investment fund has not been developed, this paper selects 64 social responsibility investment funds that have been issued in China for more than three years. The sample data of this paper are not large (64 for SRI funds and 64 for traditional funds). These funds are still operating in the market as an experimental group. In contrast, we also selected 64 traditional funds as control groups, which were established at similar times, with similar investment scales and the same type of investment. This paper extracts the data of the sample fund from the fourth quarter of 2016 to the fourth quarter of 2019 as sample data. The relevant data include information on fund subjects, net value per unit, and Morning Star Open-end Fund rating. These relevant data are derived from Guotai An Economic and Financial Research Database and Wind Database.

\subsection{Model Construction}

For Hypothesis 1, this paper selects the total return rate (Total Return for 3y) of the sample fund for the past three years as the test statistic, compares the difference between the social responsibility investment fund and the traditional fund in this statistic, and uses Mann-Whitney $\mathrm{U}$ test to test whether the sample results are statistically significant.

For Hypothesis 2, the Standard Deviation of returns is chosen to measure the volatility of the fund, and to select the $\beta$ factor of the fund to measure the systemic risk of the fund. The standard deviation of the sample fund and the $\beta$ coefficient are selected as the test statistic, and the difference between the social responsibility investment fund and the traditional fund in these two statistics is compared, and the Mann-Whitney rank sum test method is used to test whether the sample results are statistically significant.

Finally, for the third hypothesis, this paper applies the least square estimation of multiple linear regression to evaluate whether the CSR screening criterion is a positive determinant of fund performance when facing the fund investment choice. The model is as follows:

Tot.Ret. $=\beta_{0}+\beta_{1}$ CSR $+\beta_{2}$ Beta $+\beta_{3}$ Alpha $+\beta_{4}$ FundSize $+\beta_{5}$ NetAssets $+\beta_{6}$ ESB $+\varepsilon_{t}$

Among them, Tot. Ret., which is the explanatory variable, is the total return of the fund accumulated in 3 years.

The social responsibility effect is measured by the explanatory variable CSR, which is the dummy variable proposed in this paper, which is used to quantify the fund's social responsibility index [56]. If a fund selects assets in its portfolio according to its ethical and social responsibility screening strategy, its CSR is assigned a value of 1 and in other cases it is assigned a value of $0[57,58]$.

For the sample selected in this paper, as the experimental group of all socially responsible investment funds, its $\operatorname{CSR}=1$; as a control group of all traditional funds, its $\mathrm{CSR}=0$.

According to López-Arceiz [59], asset management companies are in general adapting their offering to the concerns of their institutional and private investors by proposing products that entail varying degrees and types of commitment-SRI (Socially Responsible Investment) funds, integration of CSR criteria such as Environmental, Social, and Governance, shareholder engagement, thematic investing, and so on-and have in common a respect for the values of sustainable development. 
The rest are the control variables in this model. First, according to the basic theory of fund risk assessment mentioned above, the beta coefficient of the fund is used to indicate the systemic risk of the fund; the Jensen's Alpha is used to measure the effectiveness of the selected fund. Second, the fund's thematic characteristics are represented by the fund size FundSize and the net asset NetAssets. Finally, this article uses Equity Style Box $(E S B)$ to represent the factors associated with the size of the fund's chosen investment (large, medium, and small) to know the size and style (value, balance, and growth) of the investment. Carhart [60] has proposed that when selecting the fund, we should pay attention to the scale and potential growth of the investment objects selected by the fund. ESB variable is also a dummy variable. If a sample fund invested in a large-scale venture, such as large-scale security (Large-Cap or Big-Cap) companies, the ESB value of this fund is 0 ; if the investee is a Mid-Cap or Small-Cap size, such as a small company or SMEs, the ESB value of this fund is 1 . That is, we give the value of 0 for the big companies and 1 for SMEs.

\section{Empirical Results and Analysis}

Before the hypothesis was tested using the model, the statistical analysis was performed on some qualitative characteristics of the sample data of the experimental group and control group.

\subsection{Distribution of Fund Management Companies}

Table 1 show that in the same sample number, 64 social responsibility investment funds in the experimental group were only affiliated to 24 fund management companies, while 64 traditional funds in the control group were affiliated to 60 different fund management companies. This comparison shows that the management institutions involved in social responsibility investment funds in China are very limited. Among the 24 fund management companies, 10 Sino-foreign joint venture companies have issued 28 social responsibility investment funds; in particular, the first three Chinese social responsibility investment funds before 2011 were issued by Sino-foreign joint venture fund management companies, namely Bank of China Fund Management Co., Ltd., Xingquan Fund Management Co., Ltd., and Jianxin Fund Management Co. Only after 2011 did Chinese fund companies join the ranks of socially responsible investments. This analysis shows that the social responsibility investment fund is still a new concept in China, and that the development of social responsibility investment funds is still in the initial stage.

Table 1. Management company statistics.

\begin{tabular}{cccc}
\hline & $\begin{array}{c}\text { Sino-Foreign Joint } \\
\text { Venture Company }\end{array}$ & Chinese Company & $\begin{array}{c}\text { Total Number of } \\
\text { Companies }\end{array}$ \\
\hline SRI Fund & 10 & 14 & 24 \\
\hline Traditional fund & 14 & 46 & 60 \\
\hline
\end{tabular}

\subsection{Distribution of Fund Types}

As a sample of socially responsible investment funds, there are distributions in the fund type, as nearly $60 \%$ of socially responsible investment funds are equity (stock) funds, and the remaining $40 \%$ of socially responsible investment funds are hybrid funds (see Table 2). Because the control of the fund type is controlled as much as possible in the traditional fund sample of the control group, the comparison between the two groups in the perspective of the fund type has no meaning. This paper introduces the statistics released by the Galaxy Securities Fund Research Center in January 2020:

Table 2. SRI Fund Type Statistics.

\begin{tabular}{cc}
\hline Stock Type & Hybrid (Mixed, for Example Stocks and Bonds) \\
\hline $38(60 \%)$ & $26(40 \%)$ \\
\hline
\end{tabular}


Based on the classification system of China Galaxy Securities Fund Research Center (2020 edition), China's stock fund accounts for $18 \%$ of the total fund, $40 \%$ of mixed funds, $30 \%$ of bond funds, $8.5 \%$ of currency funds, $3 \%$ of QDII funds, $0.4 \%$ of FOF (Fund of Funds) funds, and $0.2 \%$ of other funds. It can be seen that compared with traditional funds, the types of socially responsible investment funds in China are not diverse, and they are only involved in the investment types of stocks and hybrids.

\subsection{Distribution of Fund Investment Fields}

From an investment perspective, social responsibility investment funds and traditional funds tend to invest in manufacturing companies, the statistics of which are $70 \%$ in socially responsible investment funds and $60 \%$ in traditional funds in the manufacturing sector (see Table 3). By contrast, the two funds are less favored by service and information companies: Less than $30 \%$ (18/64) of social responsibility investment funds and less than $40 \%$ of traditional funds are invested in service companies, while only two of the two groups of samples involve investing in companies engaged in the information industry or related industries. By contrast, traditional funds are more evenly spread over the choice of industrial and service companies.

Table 3. Investment field statistics.

\begin{tabular}{cccc}
\hline & $\begin{array}{c}\text { Manufacturing } \\
\text { Industry }\end{array}$ & Service Industry & $\begin{array}{c}\text { Information } \\
\text { Industry }\end{array}$ \\
\hline SRI Fund & 44 & 18 & 2 \\
\hline Traditional fund & 38 & 24 & 2 \\
\hline
\end{tabular}

\subsection{Equity Style Box Distribution}

As shown in Figure 1, both socially responsible and traditional funds prefer large companies in terms of the size of their investments: $52 \%(9.52 \%+9.52 \%+33.33 \%)$ of social responsibility investment funds and $91 \%(3.12 \%+9.37 \%+78.13 \%)$ of traditional funds have chosen to invest in large securities or large companies. When we make a comparison: $47.62 \%$ in SRI fund and $(3.12 \%+6.25 \%=9.37)$ in traditional fund are relatively more important in socially responsible portfolios. Socially responsible investment funds and traditional funds are more likely to choose growth companies in terms of the style of investment they choose: $81 \%(33.33 \%+47.62 \%)$ of social responsibility investment funds and $84 \%$ of traditional funds have chosen to invest in companies with large potential growth opportunities.

\subsection{Distribution of Morningstar Open-End Fund Ratings}

Morningstar, Inc, founded in 1984 in Chicago, USA, aims to provide investors with professional financial information and analysis, as well as rating funds and stocks It has become the authority for international fund ratings. In 2003, Morningstar expanded its activities into Shenzhen, China, and began analyzing China's investment industry [61].

To calculate a fund's summary star-rating, Morningstar calculates the 3-year, 5-year, and 10-year Morningstar Return and Risk. For each time horizon, the Morningstar Risk scores are then subtracted from the Morningstar Return scores. The three numbers (one for each time horizon) are then given subjective weights [62]. Morningstar Star Ratings: Morningstar classifies each fund by using more than 3 years of performance data. Among similar funds, the funds are sorted according to the Morningstar Risk-Adjusted Return (larger to smaller). The top $10 \%$ were rated five stars; the next $22.5 \%$ were rated four stars; the middle $35 \%$ were rated three stars; then $22.5 \%$ were rated two stars; and the last $10 \%$ were rated one star. Morningstar, with a few minor exceptions, has used this same summary rating system throughout its history $[63,64]$. 
SRI fund investment stvle box

\begin{tabular}{|l|l|l|l|}
\hline $9.52 \%$ & $9.52 \%$ & $33.33 \%$ & $\begin{array}{l}\text { Large } \\
\text { Entrep }\end{array}$ \\
\hline & & $47.62 \%$ & $\begin{array}{l}\text { Middle } \\
\text { Entrep }\end{array}$ \\
\hline & & $\begin{array}{l}\text { Small } \\
\text { Entrep }\end{array}$ \\
\hline $\begin{array}{l}\text { Value } \\
\text { type }\end{array}$ & Balanced & $\begin{array}{l}\text { Growth } \\
\text { type }\end{array}$ & \\
\hline
\end{tabular}

Traditional fund investment stvle box

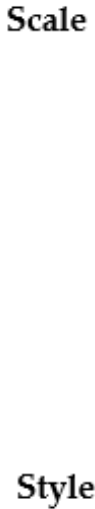

\begin{tabular}{|l|l|l|l|}
\hline $3.12 \%$ & $9.37 \%$ & $78.13 \%$ & $\begin{array}{l}\text { Large } \\
\text { Entrep }\end{array}$ \\
\hline & $3.12 \%$ & $6.25 \%$ & $\begin{array}{l}\text { Middle } \\
\text { Entrep }\end{array}$ \\
\hline & & $\begin{array}{l}\text { Small } \\
\text { Entrep }\end{array}$ \\
\hline $\begin{array}{l}\text { Value } \\
\text { type }\end{array}$ & Balanced & $\begin{array}{l}\text { Growth } \\
\text { type }\end{array}$ & \\
\hline
\end{tabular}

Scale

Style

Figure 1. ESB distribution map.

The Morningstar rating indicators can reflect the risk-return level of the fund to some extent. Table 4 depicts the ratings of two groups of sample funds on the Morningstar platform.

Table 4. Morningstar Ratings.

\begin{tabular}{|c|c|c|c|c|c|}
\hline & $\star$ & $\star \star \star$ & 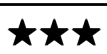 & 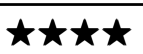 & 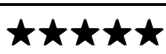 \\
\hline SRI Fund & 12 & 18 & 12 & 16 & 6 \\
\hline Traditional fund & 8 & 14 & 20 & 14 & 8 \\
\hline
\end{tabular}

Statistically, it can be seen that in the sample and when we compare our sample to the standards of [59], the socially responsible investment fund has more distributions of the two low ratings of one star and two stars than the traditional fund. The distribution of the two high ratings of four stars and five stars and the traditional funds are quite similar. Socially responsible investment funds have more four star ratings and fewer five star ratings. The traditional funds have more three star ratings than socially responsible investment funds do. In general, socially responsible investment funds score slightly lower than traditional funds. This means that the social responsibility investment fund's relative ranking in its similar funds is slightly lower than the traditional fund.

\subsection{Descriptive Statistics}

Table 5 reports descriptive statistics of key variables. The average total return of 128 sample $(64 \times 2)$ funds for the period from the fourth quarter (Trimester) of 2016 to the fourth quarter of 2019 was 1.6250, a figure that reflects the overall performance of the sample funds; Most of the sample have the ability to deliver returns to investors during that period, but a high standard deviation of 1.2210 indicates a significant difference in performance levels between each sample funds. The average standard deviation of the sample fund for indicators of the volatility of the reaction fund is 24.8471 , and there is a large or big difference between the data.

For the $\beta$ coefficient of systemic risk in response to the fund, the sample mean is 1.1561 , and the data are quite different. The Jensen's alpha index of stock selection ability in response to the fund manager is -2.1862 , and the data are quite similar. At the same time, it can be seen that there is a huge difference between the size of the fund and the net assets of the fund, which shows that the capital strength of the fund is uneven.

\subsection{Correlation Analysis}

Table 6 reports the correlation analysis between the explanatory variables. There is no serious collinearity between the two variables, the correlation coefficient is not large (i.e., less than 0.5 for all variables), and the statistical results are not significant. 
Table 5. Descriptive statistics of variables.

\begin{tabular}{ccccc}
\hline & Mean & Std. Dev. & Min & Max \\
\hline TR (Total Return) for 3y & 1.625 & 1.221 & -1.161 & 3.010 \\
\hline SD & 24.847 & 8.749 & 20.33 & 28.61 \\
\hline B & 1.1561 & 0.203 & 0.65 & 1.64 \\
\hline Jansen Index $\alpha$ & -2.186 & 0.002 & -2.21 & -1.98 \\
\hline FundSize fund scale & 16.668 & 15.216 & 2.36 & 70.53 \\
\hline NetAssets & 9.480 & 14.071 & 0.05 & 51.9 \\
\hline
\end{tabular}

Table 6. Variable correlation analysis.

\begin{tabular}{|c|c|c|c|c|c|c|}
\hline & CSR & $\beta$ & FundSize & NetAssets & $\mathbf{A}$ & ESB \\
\hline CSR & 1 & & & & & \\
\hline$\beta$ & $\begin{array}{l}-0.182 \\
(0.287)\end{array}$ & 1 & & & & \\
\hline FundSize & $\begin{array}{c}0.114 \\
(0.509)\end{array}$ & $\begin{array}{l}-0.008 \\
(0.962)\end{array}$ & 1 & & & \\
\hline NetAssets & $\begin{array}{c}0.090 \\
(0.600)\end{array}$ & $\begin{array}{c}0.106 \\
(0.537) \\
\end{array}$ & $\begin{array}{c}0.311 \\
(0.065) \\
\end{array}$ & 1 & & \\
\hline$\alpha$ & $\begin{array}{l}-0.021 \\
(0.904)\end{array}$ & $\begin{array}{l}-0.275 \\
(0.104)\end{array}$ & $\begin{array}{c}0.158 \\
(0.358)\end{array}$ & $\begin{array}{c}0.118 \\
(0.492)\end{array}$ & 1 & \\
\hline ESB & $\begin{array}{c}0.359 \\
(0.064)\end{array}$ & $\begin{array}{l}-0.069 \\
(0.691)\end{array}$ & $\begin{array}{l}-0.112 \\
(0.514)\end{array}$ & $\begin{array}{l}-0.167 \\
(0.330)\end{array}$ & $\begin{array}{l}-0.262 \\
(0.123)\end{array}$ & 1 \\
\hline
\end{tabular}

Note: $p$-Value in parentheses.

\subsection{Univariate Analysis}

Table 7 reports the analysis of the Mann-Whitney rank sum test for Hypotheses 1 and 2. Mann-Whitney rank sum test is used to test whether two samples are likely to derive from the same population (i.e., that the two populations have the same shape. The results show that the difference between the returns of social responsibility investment funds and those of traditional funds is not significant, and the risk of social responsibility investment funds is obviously lower than that of traditional funds.

In comparison with the Jensen's alpha index, the mean difference between the two funds is not significant and the statistical results are not significant. This suggests that the performance of the two types of funds is independent of the fund managers' stock selection ability. Stock selection skills include the estimation of individual stock price movements relative to the market and identification of individual stocks that overvalued and undervalued relative to the equity in general.

There is no statistically significant difference between the total returns of the two types of funds. The two-side approximate $p$-value is 0.148 , which is $10 \%$ above the significance level. This suggests that the data cannot validate Hypothesis 1, that "The return of socially responsible investment funds is higher than traditional funds". Our results are the same as those found in the report of RBC Global Asset management firm (RBC Global Asset management) [65]. In their report, they had shown that the chief finding is that socially responsible investing does not result in lower investment returns. Parallel to this, we can say that this finding is significant because it provides support to individual investors and trustees of institutional funds, so that they can pursue a strategy of socially responsible investing with the expectation that investment returns will be similar to traditional investment options. 
Table 7. Univariate analysis.

\begin{tabular}{ccccc}
\hline & SRI Mean & CF Mean & MW Test & Asymp. Sig. \\
\hline A & -2.207 & -2.165 & 2807 & 0.973 \\
\hline TR for 3y & 1.559 & 1.690 & 2661 & 0.148 \\
\hline SD & 23.925 & 25.768 & $3464^{* * *}$ & 0.004 \\
\hline B & 1.116 & 1.196 & $3658^{*}$ & 0.072 \\
\hline
\end{tabular}

Sign. level: $1 \%\left(^{* * *}\right) ; 10 \%\left(^{*}\right)$ SRI is Socially Responsible Investment and CF represents traditional funds.

The comparative analysis of the standard deviation between the two types of funds shows that the average volatility (fluctuation) of social responsibility investment funds is 23.925 , which is significantly lower than the average volatility of traditional funds of 25.768. The statistical results are significant, the $p$-Value is 0.004 , which is lower than the significance level of $1 \%$. The analysis results support Hypothesis $2 \mathrm{a}$, that the volatility of the SRI funds is lower than that of the traditional funds.

For the $\beta$ coefficient of the systemic risk (i.e., the entire risk of the industry or economy) of the reaction fund, the statistic of the social responsibility investment fund is 1.1162, which is also lower than the statistic of the traditional fund of 1.1960, and is statistically significant; in addition, the $\mathrm{p}$ value is 0.072 , which is lower than the significance level of $10 \%$. The analysis results validate the establishment of Hypothesis $2 b$, which states that "The systemic risk of social responsibility investment funds is lower than that of traditional funds". This result is the same shown by Brzeszczyński et al. [66], who found that Beta coefficients and other risk measures show that SRI funds in Poland, which were part of the RESPECT Index, were characterized by relatively lower risk than the broader market and have a better risk-adjusted performance.

\subsection{Multivariate Linear Regression Analysis}

Table 8 reports the regression analysis of the multivariate linear model established for Hypothesis 3. The results show that the correlation coefficient of the CSR as a dummy variable to the fund's return rate is 0.803 , which is statistically significant. This shows that social responsibility, as a factor affecting investment choice, has a significant positive impact on return on investment. This result verifies the establishment of Hypothesis 3 "Corporate Social Responsibility has a positive impact on fund returns". Our results are the same as those found by other researchers such as [67,68]. Giannarakis et al. [67] suggest that the involvement in socially responsible initiatives has a significantly positive effect on financial performance. Similarly, Okafor et al. [68] have shown that tech companies that spend more on CSR experience a corresponding increase in revenue and profitability.

Table 8. Regression analysis.

\begin{tabular}{ccc}
\hline \multicolumn{3}{c}{ Dep. Variable: Total Return for 3y } \\
\hline Variable & Std. Coef. & Asymp. Sig. \\
\hline CSR & $0.803^{* * *}$ & 0.005 \\
\hline A & $0.387^{* * *}$ & 0.000 \\
\hline B & $-0.68^{* *}$ & 0.050 \\
\hline FundSize & $-0.105^{*}$ & 0.095 \\
\hline NetAssets & 0.079 & 0.478 \\
\hline ESB & $-0.007^{*}$ & 0.089 \\
\hline & ANOVA test & \\
\hline Adj. R-Square $86.5 \%$ & F 124.114 & \\
\hline Sign. level: $1 \%\left({ }^{* * *}\right) ; 5 \%\left({ }^{* *}\right) ; 10 \%\left({ }^{*}\right)$. & &
\end{tabular}




\section{Discussions and Conclusions}

The originality of this paper is that we present the phenomenon of CSR in relation to the Chinese market. In our opinion, there is not a lot of research in this subject with the case of China. This paper empirically explores the performance of mutual funds in China in terms of social responsibility. With this aim in mind, the research is conducted on the basis of the verification of four hypotheses (marked with numbers-1, 2a, 2b, and 3). Socially responsible investment funds are still new in China. The size and quantity of localized socially responsible investment funds are very limited, and the selection of investment fields is narrow. Although China's social responsibility investment fund is small, it has the potential for sustainable development. For investors, social responsibility investment funds do not outperform traditional funds in terms of returns. The development of social responsibility investment funds in China will build a more green and sustainable market [8]. There is still much room for development in socially responsible investment funds in China's market.

The findings of the paper present the phenomenon of corporate social responsibility in relation to the Chinese market. The results show that the difference between the returns of social responsibility investment funds and those of traditional funds is insignificant, and the risk of social responsibility investment funds is obviously lower than that of traditional funds. The study also reveals that socially responsible investment funds are becoming a determinant of investment decisions. Corporate social responsibility as a screening indicator has a positive effect on fund performance. They have a clear advantage in risk control. Following regression analysis of social responsibility as a factor affecting the performance of the fund model, the results show that social responsibility has a significant positive impact on the fund's return in the Chinese market.

From a methodological point of view, the research in this paper is significantly different from other studies on the performance of socially responsible investment. First, previous analyses often compare market indices. This paper uses the method of introducing dummy variables to quantify the relationship between social responsibility choices and fund performance. Second, in the past, there was a large amount of empirical research focusing on western financial markets. This paper studies China's fund market and analyzes the performance of social responsibility funds in the Chinese market.

Our research has some limitations. First, the research sample and the analyzed time period are too small. That is, the time span of the research of this paper is from the end of 2016 to the end of 2019, using only one time period (i.e., 3 years). It is to be noted that we can use 3 years, 5 years, or 10 years [64]. To further study, one could increase the time period of the study and compare the empirical results over different time spans and different time nodes to ascertain whether the results are different.

Second, the sample data of this paper are not large (64 for SRI fund and 64 for traditional fund). Due to the late development of social responsibility funds in China, the number of funds available for research is small, which may lead to the research results being not representative enough.

Finally, since the United Nations proposed the concept of ESG, academic research in recent years has focused on ESG instead of CSR. We did not consider ESG in our paper because MSCI ESG officially began to analyze Chinese companies from 2018 and our data starts from 2016. This warrants conducting future research with the case of China by focusing on ESG as an explanatory variable.

Author Contributions: Conceptualization, F.S.; methodology, F.S.; software, F.S.; validation, F.S., S.M.J.; formal analysis, F.S. and S.M.J.; investigation, F.S. and S.M.J.; data curation, F.S. and M.H.; writing-original draft preparation, F.S.; writing — review and editing, F.S. and S.M.J.; visualization, F.S. and M.H.; supervision, F.S. and S.M.J. All authors have read and agreed to the published version of the manuscript.

Funding: This research received no external funding.

Institutional Review Board Statement: Not applicable. 
Informed Consent Statement: Not applicable.

Data Availability Statement: Not applicable.

Conflicts of Interest: The authors declare no conflict of interest.

\section{References}

1. Derwall, J.; Koedijk, K.; Ter Horst, J. A tale of values-driven and profit-seeking social investors. J. Bank. Financ. 2011, 35, 2137-2147. [CrossRef]

2. Arefeen, S.; Shimada, K. Performance and Resilience of Socially Responsible Investing (SRI) and Conventional Funds during Different Shocks in 2016: Evidence from Japan. Sustainability 2020, 12, 540. [CrossRef]

3. Revelli, C. Re-embedding financial stakes within ethical and social values in socially responsible investing (SRI). Res. Int. Bus. Financ. 2016, 38, 1-5. [CrossRef]

4. Matallín-Sáez, J.C.; Soler-Domínguez, A.; De Mingo-López, D.V.; Tortosa-Ausina, E. Does socially responsible mutual fund performance vary over the business cycle? New insights on the effect of idiosyncratic SR features. Bus. Ethics A Eur. Rev. 2018, 28, 71-98. [CrossRef]

5. Revelli, C. Socially responsible investing (SRI): From mainstream to margin? Res. Int. Bus. Financ. 2017, 39, 711-717. [CrossRef]

6. Renneboog, L.; Ter Horst, J.; Zhang, C. Socially responsible investments: Institutional aspects, performance, and investor behavior. J. Bank. Financ. 2008, 32, 1723-1742. [CrossRef]

7. Witt, M.A.; Redding, G. The spirits of Corporate Social Responsibility: Senior executive perceptions of the role of the firm in society in Germany, Hong Kong, Japan, South Korea and the USA. Socio-Econ. Rev. 2011, 10, 109-134. [CrossRef]

8. Climent, F.; Soriano, P. Green and Good? The Investment Performance of US Environmental Mutual Funds. J. Bus. Ethics 2011, 103, 275-287. [CrossRef]

9. Ferreira, M.; Keswani, A.; Miguel, A.; Ramos, S. The Determinants of Mutual Fund Performance: A Cross-Country Study. Rev. Financ. 2013, 17, 483-525. [CrossRef]

10. Steffen, W.; Rockström, J.; Richardson, K.; Lenton, T.M.; Folke, C.; Liverman, D.; Summerhayes, C.P.; Barnosky, A.D.; Cornell, S.E.; Crucifix, M.; et al. Trajectories of the Earth System in the Anthropocene. Proc. Natl. Acad. Sci. USA 2018, 115, 8252-8259. [CrossRef]

11. Lo, K.Y.; Kwan, C.L. The Effect of Environmental, Social, Governance and Sustainability Initiatives on Stock Value-Examining Market Response to Initiatives Undertaken by Listed Companies. Corp. Soc. Responsib. Environ. Manag. 2017, 24, 606-619. [CrossRef]

12. Sciarelli, M.; Cosimato, S.; Landi, G.; Iandolo, F. Socially responsible investment strategies for the transition towards sustainable development: The importance of integrating and communicating ESG. TQM J. 2021, 33, 39-56. [CrossRef]

13. Ryszawska, B. Sustainability transition needs sustainable finance. Copernic. J. Financ. Account. 2016, 5, 185-194. [CrossRef]

14. Crifo, P.; Durand, R.; Gond, J.-P. Encouraging Investors to Enable Corporate Sustainability Transitions: The Case of Responsible Investment in France. Organ. Environ. 2019, 32, 125-144. [CrossRef]

15. Ruscoe, G.U. “Ian I. Mitroff. Stakeholders of the organizational mind. San Francisco: Jossey-Bass Publishers, 1983, 178 pp.”-Book Review. Syst. Res. Behav. Sci. 1984, 29, 217-218. [CrossRef]

16. Freeman, R.E.; Reed, D.L. Stockholders and Stakeholders: A New Perspective on Corporate Governance. Calif. Manag. Rev. 1983, 25, 88-106. [CrossRef]

17. Qi, L.; Wang, L.; Li, W. Do mutual fund networks affect corporate social responsibility? Evidence from China. Corp. Soc. Responsib. Environ. Manag. 2020, 27, 1040-1050. [CrossRef]

18. Saci, F.; Jasimuddin, S.M.; Hoque, A. Does corporate culture matter to earnings management? Evidence from Chinese Timehonoured Brand firms. Aust. Econ. Paper 2021, 60, 435-465. [CrossRef]

19. Hamilton, S.; Jo, H.; Statman, M. Doing Well While Doing Good? The Investment Performance of Socially Responsible Mutual Funds. Financ. Anal. J. 1993, 49, 62-66. [CrossRef]

20. Abdelsalam, O.; Fethi, M.D.; Matallín, J.C.; Tortosa-Ausina, E. On the comparative performance of socially responsible and Islamic mutual funds. J. Econ. Behav. Organ. 2014, 103, S108-S128. [CrossRef]

21. Nofsinger, J.; Varma, A. Socially responsible funds and market crises. J. Bank. Financ. 2014, 48, 180-193. [CrossRef]

22. Scholtens, B. What drives socially responsible investment? The case of the Netherlands. Sustain. Dev. 2005, 13, 129-137. [CrossRef]

23. Hickman, K.A.; Teets, W.R.; Kohis, J.J. Social Investing and Modern Portfolio Theory. Am. Bus. Rev. 1999, 17, 72-78.

24. Li, L.; Jasimuddin, S.M.; Faulkner, D. Does strategic alliance matter in managing innovation in China? J. Appl. Bus. Res. 2014, 30, 793-805. [CrossRef]

25. Saci, F.; Jasimuddin, S.M. Does the research done by the institutional investors affect the cost of equity capital? Finance Research Lett. 2021, 41, 101834. [CrossRef]

26. Li, S. Ethical Investment and Its Trends. Econ. Trends 1999, 12, 1-5. (In Chinese)

27. Dai, P.; Liu, H. Practice of Social Responsibility Investment in Foreign Countries and Its Development Prospects in China. Sci. Technol. Prog. Countermeas. 2005, 7, 20-22. (In Chinese)

28. Qiao, H.; Long, W. A Review of Empirical Research on Social Responsibility Investment Performance. Economics $2009,6$. (In Chinese) 
29. Lai, J. Research on the Relationship Between Social Responsibility Investment and Performance of China's Securities Investment Funds. Master's Thesis, Guangxi University, Guangxi, China, 2016; pp. 63-67. (In Chinese).

30. Broadstock, D.C.; Chan, K.; Cheng, L.T.; Wang, X. The role of ESG performance during times of financial crisis: Evidence from COVID-19 in China. Financ. Res. Lett. 2021, 38, 101716. [CrossRef]

31. Deng, X.; Cheng, X. Can ESG Indices Improve the Enterprises' Stock Market Performance?-An Empirical Study from China. Sustainability 2019, 11, 4765. [CrossRef]

32. Zhao, C.; Guo, Y.; Yuan, J.; Wu, M.; Li, D.; Zhou, Y.; Kang, J. ESG and Corporate Financial Performance: Empirical Evidence from China's Listed Power Generation Companies. Sustainability 2018, 10, 2607. [CrossRef]

33. Guerrero, V.; Sierra, G.; Palacios, F. The role of sustainable development and innovation on firm performance. Corp. Soc. Responsib. Environ. Manag. 2018, 25, 1350-1362. [CrossRef]

34. Kushwaha, G.S.; Sharma, N.K. Green initiatives: A step towards sustainable development and firm's performance in the automobile industry. J. Clean. Prod. 2016, 121, 116-129. [CrossRef]

35. Huber, B.M.; Comstock, M.; Polk, D.; Wardwell, L.L.P. ESG Reports and Ratings: What They Are, Why They Matter. Harvard Law School Forum on Corporate Governance and Financial Regulation. Available online: https://corpgov.Law.Harvard.Edu/20 17/07/27/esg-reports-and-ratings-what-they-are-why-they-matter. (accessed on 27 July 2017).

36. Henriksson, R.; Livnat, J.; Pfeifer, P.; Stumpp, M. Integrating ESG in Portfolio Construction. J. Portf. Manag. 2019, 45, 67-81. [CrossRef]

37. Ghoul, S.; Guedhami, O.; Kim, Y. Country-level institutions, firm value, and the role of corporate social responsibility initiatives. J. Int. Bus. Stud. 2017, 48, 360-385. [CrossRef]

38. Markowitz, H.M. Portfolio Selection. J. Financ. 1952, 7, 77-91. [CrossRef]

39. Sharpe, W.F. Capital asset prices: A theory of market equilibrium under conditions of risk. J. Financ. 1964, 19, 425-442. [CrossRef]

40. Kempf, A.; Osthoff, P. The Effect of Socially Responsible Investing on Portfolio Performance. Eur. Financ. Manag. 2007, 13, 908-922. [CrossRef]

41. Freeman, R.E.; Auster, E.R. Values, Authenticity, and Responsible Leadership. J. Bus. Ethics 2011, 98, 15-23. [CrossRef]

42. Argandona, A. Three Ethical Dimensions of the Financial Crisis; IESE Business School Working Paper No. 944; University of Navarra: Madrid, Spain, 2012. [CrossRef]

43. Michelson, G.; Wailes, N.; Van Der Laan, S.; Frost, G. Ethical Investment Processes and Outcomes. J. Bus. Ethics 2004, 52, 1-10. [CrossRef]

44. Capelle-Blancard, G.; Monjon, S. The Performance of Socially Responsible Funds: Does the Screening Process Matter? Eur. Financ. Manag. 2014, 20, 494-520. [CrossRef]

45. Carswell, A. Crisis of Conscience. Aust. CPA 2002, 72, 26-27.

46. Lewies, A.; Mackenzie, C. Morals, Money, Ethical Investing and Economic Psychology. Hum. Relat. 2000, 53, 179-191. [CrossRef]

47. Inderst, G.; Kaminker, C.; Stewart, F. Defining and Measuring Green Investments: Implications for Institutional Investors Asset Allocations; OECD Working Papers on Finance, Insurance and Private Pensions, No. 24; OECD Publishing: Paris, France, 2012.

48. Jensen, M.C. The Performance of Mutual Funds in the Period 1945-1964. J. Financ. 1968, 23, 389-416. [CrossRef]

49. Orlitzky, M.; Schmidt, F.L.; Rynes, S.L. Corporate Social and Financial Performance: A Meta-Analysis. Organ. Stud. 2003, 24, 403-441. [CrossRef]

50. Renneboog, L.; TerHorst, J.; Zhang, C. The price of ethics and stakeholder governance: The performance of socially responsible mutual funds. J. Corp. Financ. 2008, 14, 302-322. [CrossRef]

51. Bringer, R.P.; Benforado, D.M. Pollution prevention and total quality environmental management. In Environmental Strategies Handbook; McGraw-Hill: New York, NY, USA, 1994; pp. 65-197.

52. Fassin, Y. Innovation and Ethics Ethical Considerations in the Innovation Business. J. Bus. Ethics 2000, 27, 193-203. [CrossRef]

53. Nielinger, O. Wirtschaft und nichtregierungsorganisationen: Eine Liaison mit Zukunft. Nord-Südaktuell 2003, 17, 126-136.

54. Margolis, J.D.; Walsh, J.P. Misery Loves Companies: Rethinking Social Initiatives by Business. Adm. Sci. Q. 2003, 48, 268-305. [CrossRef]

55. Cortez, M.C.; Silva, F.; Areal, N. The Performance of European Socially Responsible Funds. J. Bus. Ethics 2008, 87, 573-588. [CrossRef]

56. El Ghoul, S.; Karoui, A. Does corporate social responsibility affect mutual fund performance and flows? J. Bank. Financ. 2017, 77, 53-63. [CrossRef]

57. Crifo, P.; Diaye, M.-A.; Pekovic, S. CSR related management practices and firm performance: An empirical analysis of the quantity-quality trade-off on French data. Int. J. Prod. Econ. 2016, 171, 405-416. [CrossRef]

58. Benlemlih, M.; Bitar, M. Corporate Social Responsibility and Investment Efficiency. J. Bus. Ethic. 2018, 148, 647-671. [CrossRef]

59. López-Arceiz, F.J.; Bellostas-Pérezgrueso, A.J.; Moneva, J.M. Evaluation of the Cultural Environment's Impact on the Performance of the Socially Responsible Investment Funds. J. Bus. Ethics. 2016, 150, 259-278. [CrossRef]

60. Carhart, M.M. On Persistence in Mutual Fund Performance. J. Financ. 1997, 52, 57-82. [CrossRef]

61. Morningstar. The Morningstar Rating Methodology; Morningstar Publications: Chicago, IL, USA, 2003.

62. Morey, M.R. Mutual Fund Age and Morningstar Ratings. Financ. Anal. J. 2002, 58, 56-63. [CrossRef]

63. Blake, C.R.; Morey, M.R. Morningstar Ratings and Mutual Fund Performance. J. Financ. Quant. Anal. 2000, 35, 451-483. [CrossRef]

64. Blume, M.E. An Anatomy of Morningstar Ratings. Financ. Anal. J. 1998, 54, 19-27. [CrossRef] 
65. RBC Global Asset Management. Does Socially Responsible Investing Hurt Investment Returns? 2019. Available online: https:/ / www.rbcgam.com/documents/en/articles/does-socially-responsible-investing-hurt-investment-returns.pdf (accessed on 6 March 2019).

66. Brzeszczyński, J.; Gajdka, J.; Schabek, T. How risky are the socially responsible investment (SRI) stocks? Evidence from the Central and Eastern European (CEE) companies. Financ. Res. Lett. 2021, 42, 101939. [CrossRef]

67. Giannarakis, G.; Konteos, G.; Zafeiriou, E.; Partalidou, X. The impact of corporate social responsibility on financial performance. Investig. Manag. Financ. Innov. 2016, 13, 171-182. [CrossRef]

68. Okafor, A.; Adeleye, B.N.; Adusei, M. Corporate social responsibility and financial performance: Evidence from U.S tech firms. J. Clean. Prod. 2021, 292, 126078. [CrossRef] 